\title{
MEDICINE OF THE FUTURE: DIGITAL TECHNOLOGIES IN HEALTHCARE
}

\author{
Saltanat Mamyrbekova ${ }^{1,}{ }^{*}$, Zhansaya Nurgaliyeva $^{1}$, Akylbek Saktapov $^{1}$, Aizhan Zholdasbekova ${ }^{1}$, \\ Aizat Kudaibergenova ${ }^{1}$
}

${ }^{1}$ Al-Farabi Kazakh National University, al-Farabi Ave. 71, 050040 Almaty, Kazakhstan

\begin{abstract}
This article discusses the role of innovative digital technologies in medicine to improve its competitiveness and efficiency of organization and management in health care, as well as improving the quality of treatment. Health care shows the diversity of achievements and the flow of innovations based on technology. Most of the innovations that the author will describe here are still at the initial stage of development. Everyone is impressive in their own way. But the good news is that these innovations have been opened up from the traditional healthcare system to "unified medicine". The goal is to identify and prevent the disease, along with treatment. In an outdated model of medicine, the necessary data is scattered between paper files, or classified into an electronic medical record system. Today, its improved model is being implemented. This is an individual technology for continuous monitoring of vital functions and comprehensive presentation of information about the patient's health status. The development of information technologies and home selfmonitoring devices leads to the creation of convenient services for remote consultation of citizens who care about their health.
\end{abstract}

Keywords: health, digital technologies, telemedicine, wearable electronics, mobile applications, advisory portal.

\section{Introduction}

How do technology and health care work together to revolutionize global health, and how can it continue to improve our health practices? Due to to advances in technology, patients now have access to modern diagnostic tools and minimally invasive surgical procedures and cutting-edge treatments-all of which have changed the healthcare industry. Some of the technological and digital transformations that have helped develop healthcare are remote consultations, telemedicine, targeted treatment, and mobile healthcare applications [1] [2]. New tools and technologies are already beginning to excite the entire healthcare system and offer high hopes for transforming the delivery of medical services in the near future increasing efficiency and improving patient care.

The most important social task of the state is to ensure the rights of citizens to receive affordable, timely and high-quality medical care, regardless of their place of residence and social status. Progress in information, telecommunications and medical technologies has had

\footnotetext{
* Corresponding author: saltanat.mamyrbekova@kaznu.kz
} 
a significant impact on the development of fundamentally new areas of organization of medical care for the population that are successfully used in practical health care in many countries [3]. The advantages of implementing these technologies in clinical practice have been the subject of debate over the past decades.It is known that the high efficiency of clinical use of information technologies (it) is to reduce the number of complications and adverse outcomes, social and economic benefits, and improve the quality of life [4]. The use of remote fixing and transmission of physiological parameters, real-time monitoring and control, teleconsultative patients allowed to transfer the medicine to a qualitatively new level, making available round-the-clock online medical advice, preventive measures, dynamic patient monitoring, emergency control and correction of key parameters of life of the human body. The following technologies can be used for this purpose: Internet (e-mail, web sites), telephone communication (stationary, mobile), video conferencing, and others [4].

\section{Literature review}

Ziyadin S. T. (2018) noted that developing countries need to use digital technologies and related business processes and management skills in order to remain competitive in an everchanging and increasingly competitive global market. He also added that information technology implies the use of time-saving devices for accessing the information product. In many industries related to public services, it is used not so much to reduce production costs as to survive in the market. From the point of view of information systems management, information technology is considered as a strategic resource for the development of all business activity, as a way to increase the company's competitiveness [5].

According to Mandl C. D. (2014), " Robust health apps will help deliver services that should become vital for accountable health organizations seeking to improve service quality and reduce costs. In addition to precision medicine, apps can be used to analyze public health, integrate data from multiple devices that track fitness and activity, monitor and improve medication compliance, treat chronic diseases, and identify high-risk, high-cost patients and coordinate their care." Unblocking these services on a national scale without deep one-time integrations will facilitate the work of public health institutions, allowing them to reliably warn doctors about infectious diseases or drug safety problems [6].

Health care has evolved over time, and thinking about the history of medicine will always give an idea of the same concept. When the idea is considered from this point of view, it becomes clear that the field of medicine is not only an area that is Central to human life, but also a way of life in modern conditions. The reason why the area has gained so much trust, as well as the approval of people on a global scale, is the fact that there has always been surveillance, as well as adherence to accuracy [7]. Every gain in one generation is compounded by the medical practice of the next generation. In the 20th century, there was an unforgettable technological boom, and it was considered as an independent area that would be useful for society as a whole [8]. A careful look at the medical field slows down the process of mastering any new technology, especially if it is aimed at replacing existing methods of treatment, as well as performing any actions.

According to Ali Pars (2016), CEO and founder of Babylon Health, the global health sector has been slow to introduce technological and analytical innovations over the past decade . The subscription health service effectively places a General practitioner on your phone and allows you to order virtual General practitioner consultations with doctors who can monitor your health and symptoms, prescribe medications, and monitor prescriptions. Entrepreneurs, investors, and practitioners have welcomed the recent growth of the digital healthcare industry, which has led to a number of significant investment rounds, particularly in the US and Europe. 
"Healthcare accounts for $10 \%$ of UK GDP and $16 \%$ of the US, and these hundreds of billions of dollars belonging to all stakeholders, everyone who receives a salary is now interested in the existing system as well as improving the future system", he adds. He believes that this contradiction of terms is at the heart of the sluggish pace of the healthcare industry and its relationship to innovation.

This is a controversial view, contradicting many who instead attribute the slow adoption of digital technologies to complex relationships between investors, entrepreneurs, governments, private and or national health organizations, pharmaceutical companies, and their clients. Once the benefits of data, Analytics and new technologies are properly promoted, the sector is expected to move together towards a more digital future.

Simone Edelmann (2019) noted that the healthcare industry is unexpectedly slow to enter the global digital revolution, ranking in 2015 as the lowest third of industries by measured digital maturity. Compared to the changes we've seen in the financial and media industries over the past decade, the digital breakthrough in healthcare is still in its infancy. However, new tools and technologies are already beginning to excite the entire healthcare system and offer high hopes for transforming the delivery of medical services in the near future - increasing efficiency and improving patient care.

A workshop for digital health stakeholders was held in Canberra, Australia, where two key questions were addressed: 1) What is currently working and what is not working in digital health? and 2) Where should digital health go in the future? As part of the live laboratory approach, 25 participants from research, industry, patient and other health consumer groups and government participated in joint project activities aimed at stimulating ideas and discussions (Deborah Lupton, 2017).

The results of the workshop revealed that digital health technologies offer consumers, healthcare providers, community groups, and healthcare industries valuable ways to create and share information about health, medicine, and healthcare. However, members of some social groups are currently excluded from full participation in the digital health ecosystem. Mechanisms should be put in place to facilitate further consultation among the various digital health stakeholders, including patients and caregivers. The rights and responsibilities of the various stakeholders involved in connected digital health should also be better defined and highlighted. At the same time, the privacy and security of personal data needs to be protected.

\section{Methodology}

The methodological basis of the scientific article includes:

1. the philosophical method on which analytical conclusions and theories about the development of the concept of "digitalization in medicine" are based»;

2. general scientific method: analyzed the world experience of transition to the digital environment, the introduction of digitalization in medicine;

3. classification and comparative method: the most promising areas of digitalization of medicine were considered.

Recently, the ease and convenience of getting medical care from anywhere and at any time has been made possible by advances in e-health Informatics, sensor technologies, and mobile devices (such as smartphones). Central to this approach is the consideration of health and well-being throughout a person's life.

Let's consider the most promising areas of digitalization of medicine:

1. Electronic record. Today, digital technology gives us more security and freedom than the days of paper records. From lab reports to hospital stay details and prescriptions, everything can now be stored digitally. This also means that accessing information is much easier. Your digital medical records are stored in the cloud and can be accessed from anywhere. Digital 
medical technologies also facilitate information exchange and collaboration between hospitals and laboratories, and allow healthcare professionals to access information related to a patient's Allergy, even if the patient is unconscious. [9]

2. Telemedicine: a new era. A new era of modern medicine - telemedicine. With the help of telemedicine, the patient can consult a specialist anywhere in the world. This is a technology that has shortened the distance when it comes to medical consultations. It can also be a lifeguard in emergency situations where immediate emergency assistance is required. [2] In this method, devices such as video phones are used to transmit biosignals, images, and other related data between the doctor and the patient. The parties do not even need to present at the same time for this exchange to take place. For patients, this means less waiting time and faster recovery. This also means that countries that have limited access to health care now have much faster and easier access to health care when they need it. [1] Currently, the pace of adaptation and adoption of technologies in health care worldwide is largely uneven, because while developed countries have made rapid progress in this regard, developing countries have yet to catch up. However, the symbiotic relationship between technology and health care means that many countries around the world will soon pick up pace when it comes to introducing revolutionary technologies.

3. Improving patient care. Mobile apps allow patients to track doctor appointments, meals, heart rate and exercise, and health and fitness apps now offer customized solutions by tracking what people eat as well as their activity level. Some new apps allow patients to upload their prescriptions and deliver medications to their homes, saving time and money on expensive pharmacy visits, while others allow doctors to communicate directly with patients and track their vital parameters. [2] [10]

Radio frequency technology allows doctors to track the location of patients in real time, as well as their vital signs and temperature. This makes the patient available to the doctor in case of emergencies [11].

Modern technological developments such as $3 \mathrm{D}$ printing have also revolutionized patient care - it can be used to create hearing AIDS, dental devices, and prosthetics - and doctors can use virtual reality devices to relieve symptoms of anxiety and depression in the elderly and mentally ill. diseases of patients. Other technological developments, such as robotic surgical procedures, minimize the likelihood of errors during operations [12].

4. More convenient delivery. Mobile healthcare applications (mHealth) and wearable technologies can transform medical care through their ubiquity and ease of use [13]. Smartphones are already being used as a practical healthcare tool; for example, in combination with specialized devices to make certain laboratory methods for diagnosing infectious diseases available at home or in health care settings. They are also used as an adapter with electrocardiogram electrodes to transmit data for detecting silent atrial fibrillation.

5. Telemonitoring. Defined as the use of information technology to monitor patients at a distance. This review of the literature shows that the most promising applications for remote monitoring are chronic diseases such as cardiopulmonary diseases, asthma, and heart failure at home. Fetal heart rate monitoring and infant cardiopulmonary function were also monitored at a distance, as well as coagulation or activity levels of the elderly, assessed by smart home monitoring devices. Hospitals, clinics, and prisons use telemonitoring, as well as ambulances equipped with systems connected to the host hospital. Telemonitoring reduces the complications of chronic diseases through better monitoring; provides medical services without the use of hospital beds; and reduces patient travel, free time, and overall costs. Several systems have proved cost-effective. Telemonitoring is also a way to respond to new home care needs in an aging population. Real-time monitoring of patients in ambulances reduces the start time of treatment and helps to better prepare the ambulance team. Obstacles 
to telemonitoring development include the initial costs of systems, licensing of physicians and reimbursement. In the future, virtual reality, immersive environments, tactile feedback, and nanotechnology promise new ways to improve telemonitoring capabilities [14].

Remote apps extend to other specially designed wearable devices, such as smart devices in the form of patches that can continuously but unobtrusively monitor body temperature; a pair of smart glasses or a phone camera to show a sighted person in real time the visual environment of a visually impaired person to discuss them in any situation they find themselves in; or a small device that can be placed on the expectant mother's stomach to measure contractions by reading the electrical activity of the uterine muscle. All these apps make data collection and patient monitoring easier and more convenient. The potential for further application is almost limitless [11][15].

Since personal health history is an individual's primary observation of his / her own health, it is at the center of personal health self-monitoring. On the one hand, PHR can provide users with information resources to understand their personal health; on the other hand, decision support tools can be integrated into PHR to help users make healthy lifestyle choices and engage in self-care activities. Examples of modern PHR systems are Microsoft HealthVault, The Patient Portal, MyChart, and MyOscar. One 2008 study estimated that up to 70 million people in the United States have access to PHR systems. Once entered, the PHR system uses this information to provide users with a unified health record containing information about conditions and possible interactions between prescribed medications, conditions, and allergies. Patients can also keep their health records on portable storage devices (such as USB keys) or transmit health information from wearable monitoring devices to Bluetooth-enabled devices such as PDAs, mobile phones, or smartphones [16].

Web applications for self-management of chronic diseases are gaining popularity (for example, the diabetes program described by Lorig et al. Many organizations and agencies (such as the medical librarians organization, Harvard Health, and so on) Maintain reliable web resources about health (blogs, tools, illustrations, and videos). New frontiers for improving personal health and well-being include apps for smartphones and tablets, colloquially known as"apps". Smartphone apps are probably the best and most convenient way to communicate with people anywhere at any time [16]. These apps offer health assessments (for example, a BMI calculator), health activity analysis (for example, RunKeeper for tracking GPS activity during sports), awareness (for example, a CDC vaccine Schedule, Outbreaks near me-notifies users of infectious disease outbreaks worldwide), education (for example, SleepBot - plots and analyzes sleep patterns), and even prescribes treatment (for example, WebMD for iPad).

\section{$4 \quad$ Security and privacy concerns}

At this stage, we turn our attention to key security and privacy issues in the context of the IH paradigm. Medical information itself is confidential. When President Clinton introduced HIPAA, he noted that "nothing is more personal than someone's medical or psychiatric records". security Vulnerabilities in health care systems can lead to various consequences for patients, including denial of service to death. For service providers, security vulnerabilities can lead to legal sanctions, financial losses, or loss of reputation. Indeed, with the significant expansion of information sharing between multiple providers to coordinate "care" within the integrated care model, security and privacy issues have become quite complex. Moreover, some issues may have a greater impact on one feature of this paradigm than on another, for example, device and communication security issues will be more visible when monitoring and intervening in a timely manner, while application security issues are likely to be more visible on their own. 
Figure 1 classifies security and privacy issues in the IH paradigm into four levels: user, application, communication, and device.

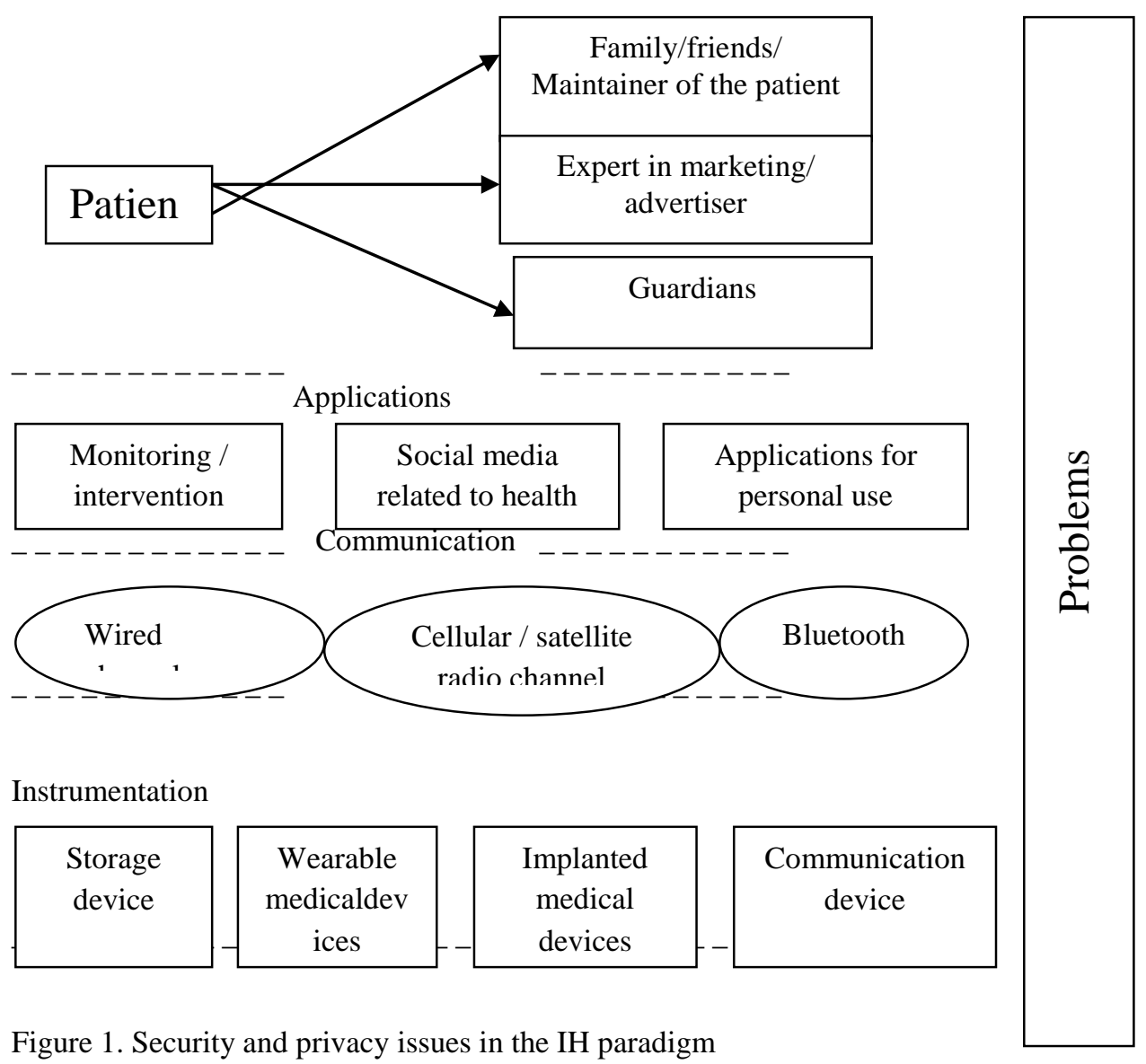

Figure 1 a patient-centered view of the healthcare paradigm anywhere and at any time: the patient uses storage devices for archiving personal medical records (PHR), wearable and implanted medical devices for continuous health monitoring and receiving interventions, and communication devices for transmitting medical information to the provider's web-based Central repositories, obtaining web-based health information, and accessing medical applications. Web communication between patients and their caregivers, friends, family, marketers, and so on takes place through various channels: wired, cellular, and satellite radio, infrared, and Bluetooth, and so on [15].

\section{$5 \quad$ Results}

Expanding access to health services. The world health organization estimates that by 2035 , the global deficit will be about 12.9 million Skilled health workers worldwide, which will 
disproportionately affect low-income countries. Digital health can be a powerful driver of improving health outcomes in these communities. This is especially true in rural or remote areas of developing countries, which have half as much access to health care as their urban counterparts. Telehealth can play an important role by connecting patients directly to doctors in remote health facilities, providing a valuable link to the health system without excessive burden. Using mobile technology to centralize the experience also helps avoid unnecessary referrals and reduces costs for patients. The introduction of digital solutions does not require the most expensive technologies - simple solutions, such as using existing SMS or mobile Internet technologies, can be very successful [15].

It should be noted that the digital technology market is a very promising niche, so investors will come to this area themselves. And there are many examples of this: Apple, Google and Samsung are interested in the problem of mobile medicine (in particular, measuring blood sugar.); IBM-image recognition and medical assistants; Google-data accumulation and analysis to support medical solutions; Microsoft-voice recognition and cloud technologies. Russian company MegaFon has launched a video consultation service "MegaFon.Health" in order to become partners of its clients not only in providing communication services, but also in organizing health care.

\section{SWOT-analysis}

\begin{tabular}{|l|l|}
\hline Strength & Weaknesses \\
\hline - Very high mobility; & - Low research and development costs; \\
- Many countries have achieved broadband & - Low mobile broadband penetration; \\
coverage for all digital agenda goals; & - There is little evidence and analysis to \\
- Relatively high availability of broadband & help countries decide whether e-health \\
connectivity; & technologies can provide significant \\
- Existing policies / strategies to support e- & savings for health systems; \\
health services; & - Lack of investment impact assessment; \\
- Ability to innovate in e-health, providing & - Low level of e-health application \\
significant cost savings and operational & development; \\
advantages for the traditional health & - Lack of interaction between e-health \\
system; & systems; \\
- Strong material and technical base of & - The main issues discussed in relation to \\
medical institutions. & privacy and security; \\
\hline Opportunities & Threats \\
\hline - General NHS reforms are taking place & - Low social readiness to accept e-health \\
(austerity measures, restructuring, etc.) that & innovations; \\
can create demand for e-health solutions; & - NHS reforms stopped (or reduced only to \\
- Population ageing: a market opportunity & reduce) when investment is needed due to \\
for multiple e-health solutions; & the economic crisis; \\
- "Low-income" populations among the & - Adoption of e-health systems often \\
poor or in remote locations can be & requires cooperation between ministries \\
considered as the main markets; & and government agencies - this may not be \\
- "Health, demographic change and well- & the case; \\
being" is defined as a social issue for which & - Problems of accreditation for healthcare \\
funding will be provided under Horizon & professionals, especially in transnational \\
2020 & organizations; \\
- Fragmentation of public demand; \\
\hline
\end{tabular}


According to the results of a number of clinical studies, including in medical organizations in Canada, Italy, Australia, England and Germany (2004-2009), the following positive trends in the implementation of it in practical health care were identified:

improved adherence to treatment, in particular according to [17] the percentage of patients who actively use home self-monitoring methods increases to $90 \%$.

decrease in the frequency of hospitalizations of patients [4].

improving the quality of life, psychological and social standing of the patient [18];

reduction of mortality among patients with cardiovascular diseases by $20-25 \%$ compared to the routine technology of medical care organization, i.e. without the use of it systems [19]; increasing patient satisfaction with medical services and improving the quality of life [20]; increasing patient awareness of their disease [21];

improving the quality of service, timely correction of drug therapy, high efficiency of drug treatment;

improving the economic efficiency of medical care [22].

Based on this, the need for global implementation of it in medicine has been confirmed by numerous studies, and at first glance there is no doubt.

The app ecosystem can also improve healthcare by combining clinical and research missions with tools that match patients and engage them in clinical trials. The first apps, based on Apple's recently released ResearchKit software environment, use modular consent and mobile data collection to make clinical trials available to everyone with an iPhone. And Apple's HealthKit infrastructure, which centralizes storage and lets you share data from health and fitness apps or something similar, could eventually become the standard interface for a patient's medical devices, such as blood glucose meters and heart monitors, as well as sensors and Wearables [6].

\section{Conclusion}

Thus, we anticipate a new wave of emerging health paradigm that is already at an early stage of development and will cover all health services around the world. This flexible, patientoriented healthcare system removes time and location restrictions for patients. The main characteristics of this paradigm include: continuous health monitoring and intervention, integrated care, self-care, and social support. With the advent of new information, communication and medical technologies, the infrastructure and support tools are already here to implement this new paradigm.

Digital technologies have already opened up many opportunities to shape the future of primary health care and ensure effective public health action. They have catalyzed many changes in education, policies, and practices, and created new models of communication, empowerment, and participation. Governments ' acceptance of the primary health care goal and its value of inclusiveness and equity promises more change, with digital technologies at the center of the vision and its implementation.

Digitalization has reached all aspects of life today and is going to change the way we, as a society, provide and consume medical services. Breakthrough technologies such as the Internet of things, artificial intelligence, blockchain, and cloud computing have matured and are being used more widely in the healthcare world. Advances in medical technologies such as genomics, wearable health products, and sensors are demonstrating growing success in medicine. Research in nanomedicine, robotics, and medical 3D printing promises to provide targeted, accurate, and timely medical services.

With the advent of new technologies, medical practice is changing. This has added to the accumulated advantages in that there is speed in the delivery of services, as well as the inclusion of medical care in the provision of assistance in the provision of services. In the field, if there is careful as well as continuous development, it is likely that this would add to 
the accumulated benefits that the current generation receives. It will also protect the practice of medicine in the sense that it will be infallible proof of errors, and the benefits can be passed on to future generations.

\section{References}

1. Zhuravleva, T.A. Innovatsionnyye tsifrovyye tekhnologii v meditsine. V sbornike: Novaya ekonomika: instituty, instrumenty, trendy, 78-82 (2018).

2. Yarmolinskiy, V. I., \& Gubkin, S. V. Tsifrovyye tekhnologii v meditsine i fizicheskoy kul'ture. Ozdorovitel'naya kul'tura molodezhi: aktual'nyye problemy i perspektivy, 119-125 (2018).

3. Serdyukov, A. G., Naberezhnaya, I. B., \& Zakharov, D. A. Sotsiologicheskoye obosnovaniye vnedreniya telemeditsinskikh tekhnologiy v praktiku. Zamestitel' glavnogo vracha, (2), 12-20 (2008).

4. Kazakov, V. N., Vladzimirskiy, A. V., \& Dorokhova, Ye. T. Telemeditsina v praktike semeynogo vracha. Ukraïns'kiy zhurnal telemeditsini i medichnoï telematiki, 3 (2), 124-130 (2005).

5. Ziyadin, S., Ermekbaeva, B., Supugaliyeva, G., Doszhan, R. Transformation of basic indicators of socio-economic processes in the digital economy, Proceedings of the $31 \mathrm{st}$ IBIMA 2018: p. 2009-2017 (2) (2018)

6. Mandl K. D., Mandel' Dzh. S., Kokheyn I. S. Driving innovation in health systems through an apps-based information economy. Cell systems, 1 (1), 8-13 (2015).

7. Pucci, J. U., Christophe, B. R., Sisti, J. A., \& Connolly Jr, E. S. (2017). Three-dimensional printing: technologies, applications, and limitations in neurosurgery. Biotechnology Advances, 35(5), 521-529.

8. Shaffer, D. V., Kigin, S. M., Kaput, Dzh. Dzh., I Gazel', G. S. What is digital medicine?. Studies in health technology and informatics, 80, 195-204 (2002).

9. Butylkina, A.A., Budnik, S.S., Velasko, A.V., Naumov, Ye.V. Rol' tsifrovykh tekhnologiy $\mathrm{v}$ razvitii sistem strakhovaniya, obrazovaniya i meditsiny. V sbornike: Ekonomicheskoye obrazovaniye dlya studentov i abituriyentov: novyye vozmozhnosti, 127-131 (2018).

10. Kheyr, S.Dzh. Materialy simpozimu «Tsifrovyye tekhnologii v meditsine». Vestnik aritmologii (40), 69-76 (2005).

11. Ben-Assuli, O. (2015). Electronic health records, adoption, quality of care, legal and privacy issues and their implementation in emergency departments. Health Policy, 119(3), 287-297.

12. Vladimirova, A. N., Gerasimova, O. YU. Ispol'zovaniye tekhnologii 3D-pechati v meditsine. Sovremennyye problemy razvitiya tekhniki, ekonomiki i obshchestva, 4547(2017).

13. Phillips, K. A., Douglas, M. P., Trosman, J. R., \& Marshall, D. A. (2017). "What goes around comes around": lessons learned from economic evaluations of personalized medicine applied to digital medicine. Value in Health, 20(1), 47-53.

14. Nangalia, V., Prytherch, D. R., \& Smith, G. B. (2010). Health technology assessment review: Remote monitoring of vital signs-current status and future challenges. Critical Care, 14(5), 233.

15. Ivanova, L. V. Tsifrovyye tekhnologii v razvitii zdravookhraneniya. Sovremennoye obrazovaniye: ochevidnoye razvitiye. Tsifrovizatsiya ekonomiki i obshchestva: vyzovy dlya sistemy obrazovaniya, 350-363 (2018).

16. Anvar, M., Dzhoshi, Dzh. \& Tan, Dzh. Anytime, anywhere access to secure, privacyaware healthcare services: Issues, approaches and challenges. Health Policy and Technology, 4 (4), 299-311 (2015). 
17. Vudvord Dzh., Eldridzh D. Kompleks, priverzhennost', soglasiye - delo ne v nazvanii. Novaya meditsina tysyacheletiya, 16-19 (2011).

18. Inglis, K. R., Makalister, F. Strukturnaya podderzhka po telefonu ili telemonitoringa programm dlya patsiyentov s khronicheskoy serdechnoy nedostatochnost'yu. Kokranovskaya baza dannykh sistematicheskikh obzorov, (8), (2010).

19. Vasil'kov, V.G., Shchukin, V.S. Vozmozhnosti ispol'zovaniya telekommunikatsionnykh tekhnologiy $\mathrm{v}$ meditsine kriticheskikh sostoyaniy (Obzor literatury, chast' 1). Vestnik intensivnoy terapii, 3-6 (1998).

20. Kolesnik, A.YU. Mezhdunarodnyy opyt monitoringa meditsinskikh uslug i otsenki rezul'tativnosti v sfere zdravookhraneniya. Analiticheskaya zapiska. USAID (2005).

21. Raposo, M. L., Alves, H. M., \& Duarte, P. A. (2009). Dimensions of service quality and satisfaction in healthcare: a patient's satisfaction index. Service Business, 3(1), 85-100.

22. Vasil'kov, V. G., Safronov, A. I. Telekommunikatsionnyye tekhnologii i razvitiye sluzhby meditsiny kriticheskikh sostoyaniy. Inform. tekhnol, 6, 48-50 (2000). 